\title{
Occult Hepatitis C Virus in Blood Donors in Damietta - Egypt
}

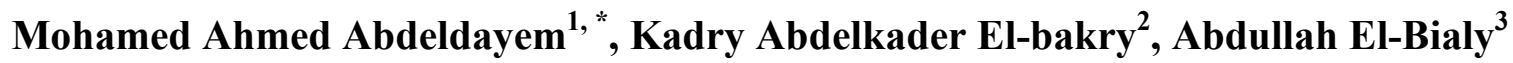 \\ ${ }^{1}$ Department of Zoology, Faculty of Science, Damietta University, Damietta, Egypt \\ ${ }^{2}$ Department of Physiology, Faculty of Science Damietta University, Damietta, Egypt \\ ${ }^{3}$ Department of Medical Microbiology and Immunology, Faculty of Medicine, Zagazig University, Zagazig, Egypt
}

Email address:

dr_Biolab@yahoo.com (M. A. Abdeldayem)

${ }^{*}$ Corresponding author

\section{To cite this article:}

Mohamed Ahmed Abdeldayem, Kadry Abdelkader El-bakry, Abdullah El-Bialy. Occult Hepatitis C Virus in Blood Donors in Damietta Egypt. American Journal of Laboratory Medicine. Vol. 4, No. 3, 2019, pp. 53-59. doi: 10.11648/j.ajlm.20190403.11

Received: April 30, 2019; Accepted: June 2, 2019; Published: June 24, 2019

\begin{abstract}
Egypt maintains the highest prevalence of hepatitis C virus infection, affecting an estimated $15 \%-20 \%$ of the population, new cases reported, so we search about uncommon source of hepatitis $\mathrm{C}$ virus infection. Occult hepatitis $\mathrm{C}$ Virus infection can be detected and founded in the overall public obviously haven't any diseases, Detection of viral replication in PBMCs may increase spread and transmission of hepatitis $\mathrm{C}$ virus during blood transfusion, hemodialysis, and made liver disease development in occult Hepatitis C Virus infected individual. The present study aimed to detect the occult hepatitis $\mathrm{C}$ virus infection in healthy blood donors from Damietta-Egypt, And detection of Hepatitis C Virus core antigen. One hundred and fifty blood donors from El-Azhar University Hospital blood bank in New Damietta City were used into the present study. Detection of Hepatitis C Virus RNA in Peripheral blood mononuclear (PBMCs) and plasma by reverse transcription nested polymerase chain reaction (RT-PCR), and also detection of hepatitis $\mathrm{C}$ virus core antigen from plasma by ELISA. We founded that: Detection of hepatitis C virus RNA by nested PCR from PBMC among studied donors are eleven (7.9\%) on the other hand Hepatitis C Virus RNA in plasma are two (1.4\%) so occult C virus are 9/140 (6.4\%). By comparison between results of Hepatitis C Virus core Ag and PCR evidence sensitivity $27 \%$, specificity $98.4 \%$ in PBMC and sensitivity $100 \%$, specificity $97.8 \%$ in Plasma.
\end{abstract}

Keywords: Hepatitis C Virus, Occult Hepatitis C Virus, PBMCs, Hepatitis C Virus Core Ag

\section{Introduction}

Hepatitis C Virus diagnosed by detects presence of Hepatitis $C$ Virus antibodies [1] with or without detection of hepatitis $C$ virus RNA in serum and plasma [2]. Occult hepatitis $C$ virus is a (diverse) than hepatitis $C$ virus was first described in 2004 and defined as the detection of hepatitis $C$ virus RNA in the liver or PBMCs of patients whose serum tests tried negative for hepatitis $C$ virus RNA by ordinary PCR examines, even presence or absence hepatitis $C$ virus antibodies [3]. Occult hepatitis $C$ virus can detected and founded in the overall public obviously haven't any diseases, Detection of viral replication in PBMCs may increase spread and transmission of hepatitis $C$ virus during blood transfusion, hemodialysis, and made liver disease development (e.g. liver cirrhosis and liver necrosis) in occult hepatitis $C$ virus infected individual [4]. Even detection the presence of hepatitis $C$ virus -RNA in liver biopsy sample is the best technique and more accurate method for the detection of occult hepatitis $C$ virus, we can detect hepatitis $C$ virus -RNA in PBMCs when we can't take liver biopsy [5, $6]$.

Hepatitis $C$ virus core Ag consists of 191 amino acids and most founded in cytoplasm [7, 8]. During the seroconversion period and before presence of antibodies we can use hepatitis $C$ virus core $\mathrm{Ag}$ for detection hepatitis $C$ virus $[9,10]$, in plasma or blood transfusion in many countries [11]. 


\section{Materials and Methods}

\subsection{Study Population}

One hundred and fifty blood donors from El-Azhar University Hospital blood bank in New Damietta City were incorporated into this study. These cases were 15 females and 135 males. All of them were apparently free from liver diseases and negative for Hepatitis C virus IgG by ELISA.

\subsection{Samples Were Negative Hepatitis C Virus Antibodies Subjected to the Following Procedure}

\subsubsection{Peripheral Blood Monocyte (PBMCs) and Plasma} Isolation

i Isolation of Peripheral Blood Mononuclear Cells (PBMC):

Heparinized blood was diluted by $1: 1$ with phosphate buffer saline (PBS) and mixed gently by inversion In Falcon tubes then centrifuged for $30 \mathrm{~min}$ to obtain visible pellet of PBMCs at the bottom of each tube.

ii Plasma isolation:

Heparinized blood was centrifuged for 15 minutes to remove cells and platelets and obtain supernatant of plasma.

\subsubsection{Extraction of Hepatitis C Virus RNA from PBMCs and Plasma}

Using viral Gene-spin ${ }^{\text {TMK }}$ it and Tanami Virus RNA Kit in PBMCs and plasma respectively using manufacturer's catalog to extract RNA in microfuge tube then at $-20^{\circ} \mathrm{C}$ will store till used.

\subsubsection{RT-Nested Polymerase Chain Used for Detect Hepatitis C Virus RNA}

Hepatitis $C$ virus RNA from PBMC and plasma was subjected to Nested PCR cycles using in the first round PCR Maxim RT-PCR Premix Kit and in the second round PCR Master Mix kit then by using agars gel electrophoresis examined under the UV illuminator to give band at $236 \mathrm{bp}$ in positive sample and negative sample give no band.

\subsubsection{Hepatitis C virus Core Antigen Detection from Plasma by ELISA}

Hepatitis $C$ virus Antigen measured according to the manufacture instructions by ELISA technique to read the Absorbance and optical density of samples.

\section{Results}

\subsection{Demographic Characteristics of Negative Hepatitis C Virus Antibodies Blood Donor Samples}

This table shows that most blood donors were males in middle age group (25-35years) and from rural distribution. Seven of them made dental and surgery procedures and five had previous blood transfusion.
Table 1. Demographic characteristics of negative hepatitis C virus antibodies blood donor samples.

\begin{tabular}{|c|c|c|}
\hline Socio demographic data & $(\mathrm{No}=140) \mathrm{No}$ & $\%$ \\
\hline \multicolumn{3}{|l|}{ Age (years) } \\
\hline $18-25$ & 50 & 35.7 \\
\hline $25-35$ & 61 & 43.6 \\
\hline $35-45$ & 29 & 20.7 \\
\hline \multicolumn{3}{|l|}{ Mean $\pm \mathrm{SD}=30.1 \pm 7.5$} \\
\hline \multicolumn{3}{|l|}{ Sex } \\
\hline Female & 13 & 9.3 \\
\hline Male & 127 & 90.7 \\
\hline \multicolumn{3}{|l|}{ Past history } \\
\hline Jaundice & 0 & 0.0 \\
\hline Drug intake & 0 & 0.0 \\
\hline Surgery and dental procedures & 7 & 5.0 \\
\hline Previous blood transfusion & 5 & 3.6 \\
\hline \multicolumn{3}{|l|}{ Residence } \\
\hline Rural & 81 & 57.9 \\
\hline Urban & 59 & 42.1 \\
\hline
\end{tabular}

\subsection{Positive Hepatitis C Virus Antibodies by Elisa}

This table shows that the detection of Hepatitis C Antibodies by Eliza among studied blood donors was Ten $(6.7 \%)$ while $140(93.3 \%)$ were negative

Table 2. 10 blood donors sample are positive hepatitis $C$ virus Antibodies by Elisa so they excluded.

\begin{tabular}{|c|c|c|}
\hline & $($ No. $=150)$ No. & $\%$ \\
\hline \multicolumn{3}{|c|}{ Hepatitis $\mathrm{C}$ virus Antibodies } \\
\hline Positive & 10 & 6.6 \\
\hline Negative & 140 & 93.3 \\
\hline
\end{tabular}

\subsection{Detection of Hepatitis C Virus RNA from PBMC and Plasma}

This table shows that the detection of Hepatitis $\mathrm{C}$ virus by nested PCR in PBMC among studied blood donors was eleven (7.9\%) while $129(92.1 \%)$ were negative. On the other hand detection of Hepatitis $\mathrm{C}$ virus by nested PCR in Plasma among considered blood donors was two (1.4\%) while 138 $(98.6 \%)$ were negative result

Table 3. Detection of hepatitis $C$ virus RNA by RT-nested Polymerase chain (PCR) from PBMC and plasma.

\begin{tabular}{|c|c|c|}
\hline & $($ No. $=140)$ No. & $\%$ \\
\hline \multicolumn{3}{|c|}{ PCR (PBMC) } \\
\hline Positive & 11 & 7.9 \\
\hline Negative & 129 & 92.1 \\
\hline \multicolumn{3}{|c|}{ PCR (Plasma) } \\
\hline Positive & 2 & 1.4 \\
\hline Negative & 138 & 98.6 \\
\hline
\end{tabular}

\subsection{Relation Between the Results PBMC \& Plasma}

Table 4 and figure 1 represents that eleven cases were positive from PBMC of studied blood donors, two of them were also positive in plasma so they were considered false negative by ELISA analysis, the occult cases were nine (6.4\%) which (Positive in PBMC and negative by plasma). 
Table 4. Relation between the results of RT- nested Polymerase chain (PCR) for PBMC \& plasma.

\begin{tabular}{llll}
\hline & \multicolumn{2}{l}{ PCR (PBMC) } & \\
\cline { 2 - 4 } & Positive cases & Negative cases & Total \\
\hline PCR (plasma) & & 0 & \\
(+VE) cases & 2 & 129 & 2 \\
(-VE) cases & 9 & 129 & 138 \\
Total & 11 & & 140 \\
\hline
\end{tabular}

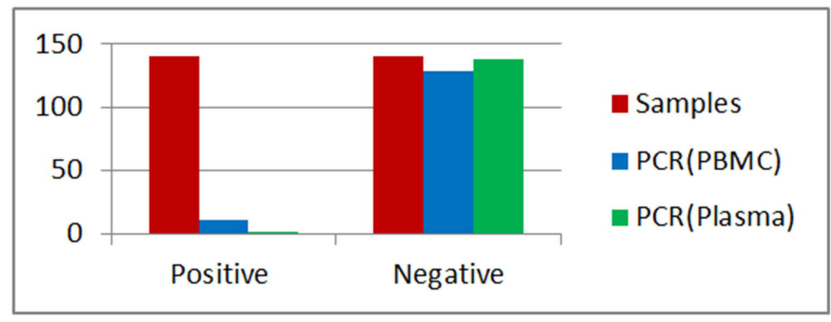

Figure 1. Relation between $P C R$ results for $P B M C$ \& plasma.

Agars gel electrophoresis results:

Figure 2 shows amplification results of hepatitis $C$ virus RNA by RT-Nested PCR in PBMC. Lane 1 is $100 \mathrm{Bp}$ molecular weight marker, lane $2 \& 3$ is positive and negative control respectively, lanes 6,8 are positive results and lanes 4, 5, 7 are negative.

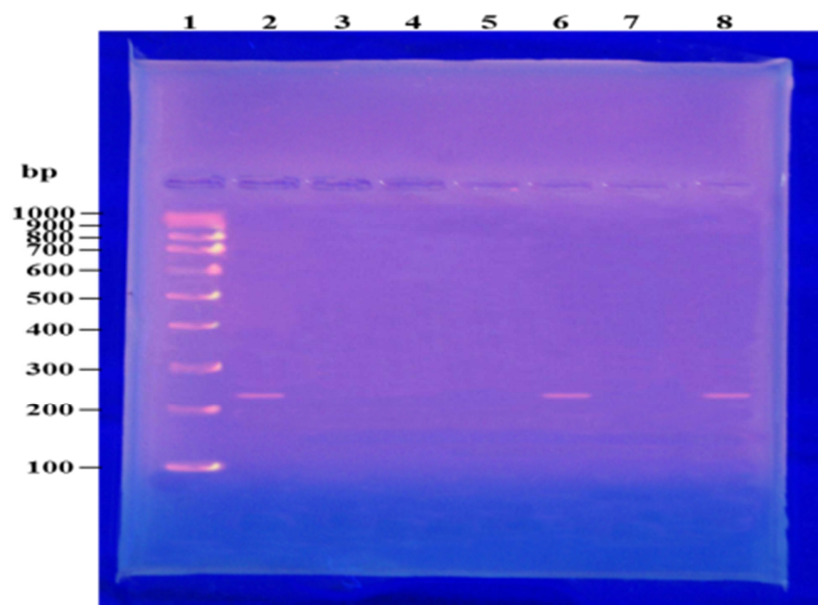

Figure 2. Agars gel electrophoresis.

\subsection{Detection of Hepatitis C Virus Core Antigen by ELISA}

This table shows that out of 140 hepatitis $C$ virus Antibodies negative tested blood donors, only five (3.6\%) were positive for core antigen detection by ELISA.

Table 5. Detection of hepatitis C virus core antigen by ELISA.

\begin{tabular}{lll}
\hline & (No.=140) No. & $\%$ \\
\hline ELISA (hepatitis $C$ virus core Ag): & & \\
\hline Positive & 5 & 3.6 \\
Negative & 135 & 96.4 \\
\hline
\end{tabular}

\subsection{Relation Between Core Antigen and PCR of (PBMC\&Plasma)}

Table 6 and figure 3 shows that only three cases were detected by ELISA out of eleven cases positive for hepatitis
$C$ virus RNA by PCR (PBMC), there was two false positive cases by ELIZA. Two cases of the HEPATITIS C VIRUS RNA by PCR (plasma) positive were also positive by ELISA; this concludes that there were three false positive cases by ELISA so sensitivity $27 \%$, specificity $98.4 \%$ in PBMC but we founded sensitivity $100 \%$ and specificity $97.8 \%$ in Plasma.

Table 6. Relation between results of hepatitis $C$ virus core antigen and PCR of (PBMC\&Plasma).

\begin{tabular}{llllll}
\hline & \multicolumn{2}{l}{ PCR (PBMC) } & \multicolumn{2}{l}{ PCR (Plasma) } & \multirow{2}{*}{ Total } \\
\cline { 2 - 5 } & $\begin{array}{l}\text { (+VE) } \\
\text { cases }\end{array}$ & $\begin{array}{l}\mathbf{( - V E )} \\
\text { cases }\end{array}$ & $\begin{array}{l}\text { (+VE) } \\
\text { cases }\end{array}$ & $\begin{array}{l}\mathbf{( - V E )} \\
\text { cases }\end{array}$ & \\
\hline ELISA & & & & & \\
$(+\mathrm{VE})$ Cases & 3 & 2 & 2 & 3 & 5 \\
$(-\mathrm{VE})$ Cases & 8 & 127 & 0 & 135 & 135 \\
Total & 11 & 129 & 2 & 138 & 140 \\
\hline
\end{tabular}

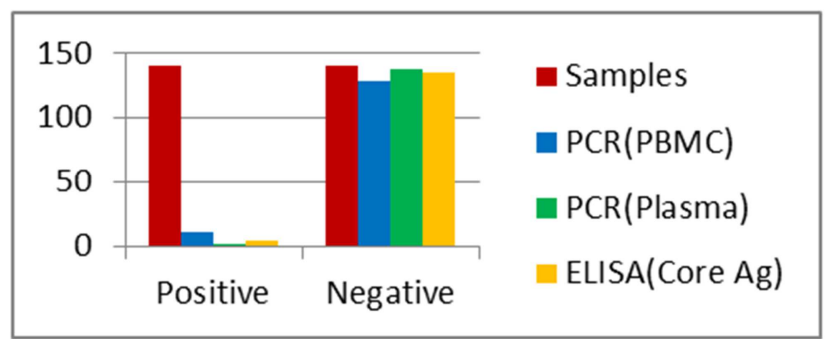

Figure 3. Relation between results of hepatitis $C$ virus core antigen by Elisa and results of hepatitis $C$ virus RNA by RT-Nested PCR of (PBMC\&Plasma).

\subsection{Correlation between ELISA and PCR in Detection of Occult Hepatitis C Cases}

This table shows that only one case of OCI (11.1\%) was detected by both ELISA and PCR and it was statistically significant $\mathrm{P}$. value $=0.003$.

Table 7. Correlation between ELISA for detection of hepatitis $C$ virus core antigen and nested PCR (PBMC) in detection of OCI cases.

\begin{tabular}{|c|c|c|c|c|c|c|}
\hline & \multirow{2}{*}{$\begin{array}{l}\text { Total } \\
\text { No. }\end{array}$} & \multicolumn{2}{|c|}{ Positive OCI } & \multicolumn{2}{|c|}{ Negative OCI } & \multirow{2}{*}{ Value } \\
\hline & & No. & $\%$ & No. & $\%$ & \\
\hline ELISA (+VE) & 9 & 1 & 11.1 & 8 & 88.9 & $0.003^{*}$ \\
\hline
\end{tabular}

\subsection{General Characteristics and Results of Nested PCR}

This table shows that $55 \%$ of hepatitis $C$ virus positive cases concentrated in age group (35-45years) and it was statistically significant, $P$. value $=0.043$ and $73 \%$ of positive cases were from rural residence but was insignificant.

Table 8. General characteristics and results of nested PCR.

\begin{tabular}{|c|c|c|c|c|c|c|}
\hline \multirow{2}{*}{$\begin{array}{l}\text { demographic } \\
\text { characteristics }\end{array}$} & \multicolumn{2}{|c|}{$\begin{array}{l}\text { PCR (+VE) } \\
\text { No. }=11\end{array}$} & \multicolumn{2}{|c|}{$\begin{array}{l}\text { PCR (-VE) } \\
\text { No. }=129\end{array}$} & \multirow[t]{2}{*}{$X^{2}$} & \multirow[t]{2}{*}{ P. value } \\
\hline & No. & $\%$ & No. & $\%$ & & \\
\hline \multicolumn{7}{|l|}{ Age (years) } \\
\hline $18-25(50)$ & 2 & 18.0 & 48 & 37.2 & \multirow{4}{*}{5.91} & \multirow{4}{*}{$0.043 *$} \\
\hline $25-35(61)$ & 3 & 27.0 & 58 & 45.0 & & \\
\hline $35-45$ (29) & 6 & 55.0 & 23 & 17.8 & & \\
\hline Sex & & & & & & \\
\hline Female (13) & 1 & 9.0 & 12 & 9.3 & \multirow[t]{2}{*}{0.15} & \multirow[t]{2}{*}{0.731} \\
\hline Male (127) & 10 & 91.0 & 117 & 90.7 & & \\
\hline
\end{tabular}




\begin{tabular}{|c|c|c|c|c|c|c|}
\hline \multirow{2}{*}{$\begin{array}{l}\text { demographic } \\
\text { characteristics }\end{array}$} & \multicolumn{2}{|c|}{$\begin{array}{l}\text { PCR (+VE) } \\
\text { No. }=11\end{array}$} & \multicolumn{2}{|c|}{$\begin{array}{l}\text { PCR (-VE) } \\
\text { No. }=129\end{array}$} & \multirow[t]{2}{*}{$X^{2}$} & \multirow[t]{2}{*}{ P. value } \\
\hline & No. & $\%$ & No. & $\%$ & & \\
\hline \multicolumn{7}{|l|}{$\begin{array}{l}\text { Geographic } \\
\text { distribution }\end{array}$} \\
\hline Rural (81) & 8 & 73.0 & 73 & 56.6 & 0.82 & 0.329 \\
\hline Urban (59) & 3 & 27.0 & 56 & 43.4 & & \\
\hline
\end{tabular}

$*=$ Significant

$\mathrm{X} 2=$ Chi- square test

\subsection{Relation Between Past History and Results of Occult Hepatitis C Virus (OCI)}

This table shows that previous blood transfusion, dental and surgery procedures were statistically significant as a risk factor predisposing to OCI among collected data about past history.

Table 9. Relation between past history of considered blood donors and results of Occult hepatitis $C$ virus (OCI).

\begin{tabular}{|c|c|c|c|c|c|c|}
\hline \multirow[t]{2}{*}{ Past history } & \multirow{2}{*}{$\begin{array}{l}\text { Total } \\
\text { No } 11\end{array}$} & \multicolumn{2}{|c|}{ +VE OCI 9} & \multicolumn{2}{|c|}{$\begin{array}{l}\text {-VE hepatitis } \\
\text { C virus } 131\end{array}$} & \multirow[t]{2}{*}{ P. Value } \\
\hline & & No. & $\%$ & No. & $\%$ & \\
\hline Jaundice & 0 & 0 & 0.0 & 0 & 0.0 & ------- \\
\hline Drug intake & 0 & 0 & 0.0 & 0 & 0.0 & ---------- \\
\hline $\begin{array}{l}\text { Surgery and } \\
\text { dental procedures }\end{array}$ & $7(5.0)$ & 4 & 44.4 & 3 & 2.3 & $0.001 * *$ \\
\hline $\begin{array}{l}\text { Previous blood } \\
\text { transfusion }\end{array}$ & $5(3.6)$ & 3 & 33.3 & 2 & 1.5 & $0.01 * *$ \\
\hline
\end{tabular}

----- =invalid

** = high significant

\section{Discussion}

High prevalence hepatitis $C$ virus infection and high rate of spread infection and liver disease without known the reason [12] so, the present study was done to detect occult hepatitis $C$ virus in healthy blood donors in Damietta city and its association to different factors e.g.: sex, age, residence, previous blood transfusion, dental procedures and surgery.

This was by hepatitis $C$ virus RNA detecting in PBMC using RT- PCR [13] without the taken a liver biopsy [14] in absence of serum antibodies [15] and also to evaluate role of hepatitis $C$ virus core $\mathrm{Ag}$ assay in detection of occult hepatitis $C$ virus [16]. The results in this study was $(7.9 \%)$, which is near to the results of other study performed by Mustafa et al. (2013) [17] reported that the detection of OCI in Egyptian volunteer blood donors (5.5\%). Fewer rates were detected in Italy by De Marco et al., (2009) [18] found OCI (3.3\%) in blood donors due to lower infection of hepatitis $C$ virus. High rate $(8.9 \%)$ detected by Kevin and his colleagues [19] in liver transplant with cryptogenic cirrhosis. Also, high rate (20\%) reported by Samir et al., (2012) [20] in patients with chronic lymph-proliferative disorder in Kasr El-Eini Hospital in contrast report low rate (4\%) in healthy individual.

Detection hepatitis $C$ virus RNA in plasma in this study $(1.4 \%)$, this reveal false negative among negative result for hepatitis $C$ virus Antibodies which done already in blood bank laboratory, because of error technique or blood donors in serocoversion period before appearance antibodies, so the true detection of OCI in our study was nine out of 140 (6.4\%). This result closed to other investigation of Shazly et al. (2015) [21] who documented that OCI was $4 \%$ in healthy Egyptian individual partners of patients infected with chronic HEPATITIS C VIRUS genotype 4 infection. Also in hemodialysis patients Abdurrahman et al. (2016) [22] detect OCI $(3.7 \%)$ in 81 at Mania- Egypt, Also Maria de la Luz Martinez-Rodríguez 2018[23] in Mexico City documented OCI 3.4\% in blood donors Samples, Lin H 2016 documented OCI 2.2\%in China [24] and Quinoa JA 2016 OCI is $2.1 \%$ Spain [25].

January 2002 European blood bank use either hepatitis $C$ virus core $\mathrm{Ag}$ or hepatitis $C$ virus RNA in blood donation test to decrease risk of spread hepatitis $C$ virus infection [26], over the last decade hepatitis $C$ virus core Ag used to complement hepatitis $C$ virus RNA or RT nested PCR in blood test [27], In addition can used for control antiviral therapy as well as for detection of hepatitis $C$ virus infection [28].

This study found that the Prevalence of hepatitis $C$ virus core antigen by ELISA technique among studied blood donors for detection of hepatitis C virus was five (3.6\%) and this result was near to result reported by and Obeid (2004) [29] who detect hepatitis $C$ virus core Ag (2\%) in negative blood donors sample, (negative hepatitis $C$ virus Antibodies) at King Fahd University Hospital. While the result of other study performed by Gaudy et al., (2005) [30] were less than these finding $(0.7 \%)$. They performed test in negative sample with high liver enzymes. This difference due to many places of the researches and variation in kits used or reagents, ELISA technique for detection hepatitis $C$ virus core Ag it's more simple and easy to done in different laboratory and cost a little, and also decrease contamination and false positive result in PCR technique and can performed fast in most laboratories [31].

Hepatitis $C$ virus core Ag results different when compared with results of RT-nested PCR from PBMCs and plasma. Only three positive samples detected of hepatitis $C$ virus core Ag out of eleven positive hepatitis $C$ virus RNA by PCR in PBMCs, $27 \%$ sensitivity and $98.4 \%$ specificity while the both two positive sample of hepatitis $C$ virus RNA by PCR in Plasma are positive in hepatitis $C$ virus core Ag by ELISA while the three other positive sample of hepatitis $C$ virus core Ag are negative in plasma, $100 \%$ sensitivity and $97.8 \%$ specificity, However; this results different from reported by Daniel and his colleagues (2007) [23] who detect the sensitivity (85.3\%) and specificity $(95.8 \%)$ when evaluate the role of HEPATITIS C VIRUS core $\mathrm{Ag}$ as a sign of active HEPATITIS C VIRUS infection compared to results of PCR, Also, Gaudy et al., 2005 [30] detect sensitivity (85.3\%) and specificity (99.3\%) in routine examination of individual and compared with results of hepatitis $C$ virus RNA detection.

Only one case $(11.1 \%)$ in this study of nine occult hepatitis $C$ virus samples detected by hepatitis $C$ virus core $\mathrm{Ag}$, however Juan and his colleagues 2006 [32] detected 4 cases 
(3.4\%) in 115 negative individual Also Alzahrani and Obeid 2004 [33] detected (2\%) of hepatitis C virus core Ag in negative hepatitis $C$ virus Antibodies in blood donors samples at King Fahd University Hospital.

In this study the relation between different demographic feature and hepatitis $C$ virus RNA results first in age was $55 \%$ of hepatitis $C$ virus positive cases founded in group their age from 35 to 45 years this result has high significance P. value $=0.043$ and compatible with that reported with Castillo et al., (2005) [34] who founded that occult hepatitis $C$ virus results in group range from 40 to 52 years and also Castillo et al., (2007) [35] reported occult hepatitis $C$ virus cases centered around 46 years in patient have dual infection $\mathrm{HBV}$ and hepatitis $C$ virus to those of patients have single occult $\mathrm{HBV}$ or hepatitis $C$ virus infection. Also, L'opezAlcorocho et al., (2007) [36] reported occult hepatitis $C$ virus centered around 42 years and $\mathrm{p}$ value was 0.1 .

In any case, relationship with more seasoned age wasn't set in every single linked examination. Samir et al. (2012) [37] detected occult hepatitis $C$ virus in younger age (18 years) because they perform their study on patients with chronic lymph proliferative upset. But it reported insignificant by Sad et al. (2011) [38] P. value was (0.646).

Second, related to the sex of the donors, it was insignificant $P$. value was (0.716). The same result was reported by Sad et al. (2011) who reported P. value (1.0) which insignificant. While, this was not in agree with other research done by Samir et al. (2012) who found that the male sex is the prevalent to OCI which may be due to more exposure. Because of, female's number in the investigation is low made it hard to estimate a strong relationship respect to this point. More numbers are expected to evaluate any possible relation between the sex and OCI.

Finally, it was insignificant in different geographic distribution (rural or urban) P. value was (0.345) and this also documented by Sad et al. (2011). Different studies needed to exclude or approve any association between occult hepatitis $C$ virus and geographic distribution of the individual. Many different factors affected to OCI also examined, by studying combination with previous blood transfusion, surgery, dental procedures, jaundice, drug intake, and fever. It was high significant between these factors especially history of previous blood transfusion, this result was agreed with kelvin et al. (2013) [39] who documented high significant P- value (0.02) in blood transfusion and P- value $(0.001)$ in past history of travel to endemic places meanwhile, $\mathrm{p}$ - value in dental procedures is 0.601 and $\mathrm{p}$ - value in surgery is 0.938 were insignificant. Also, Abdel Rahim and his coworkers (2016) [40] found that blood transfusion statistically highly significant, $\mathrm{P}$ value was 0.002. On contrary, Samir et al. (2012) documented that blood transfusion was insignificant as possible risk factor. Many different researches are needed to detect the any risk factors for transmission occult hepatitis $C$ virus.

\section{Conclusions}

Occult hepatitis $C$ virus infection may occur in the general population apparently diseases free. The presence of hepatitis $C$ virus infection in general population seems that occult hepatitis $C$ virus infection should be considered and blood transfusion may never be completely risk-free.

The hepatitis $C$ virus core Ag assay does not improve the routine serological diagnosis of occult hepatitis $C$ virus infection. Core antigen assay requires further evaluation prior to its use as a screening assay in blood banks. PCR is deemed to be more reliable than the hepatitis $C$ virus core Ag assay.

\section{Conflict of Interest}

The authors declare no conflict of interests.

\section{Acknowledgements}

The study was supported by Damietta University, Faculty of science Department of Zoology.

\section{References}

[1] Lehman E M and Wilson M 1, (2009): Epidemic Hepatitis virus infection in Egypt: Estimates of past incidence and future morbidity and mortality. J Viral Heat 16 (9): 650-658.

[2] Pawlotsky JM, London I, Hexode C, Reynard B, Arthur F, Rehire J, Sousse CJ, Dhumeaux D. (1998): How diagnosis of Hepatitis $\mathrm{C}$ virus infection in clinical laboratories? Hematology; 27: 1700-1702.

[3] Castillo I, Prado M, Bartolommeo J, Ortiz-Moville N, Rodríguez- Indigo E, de Lucas S, Salas C, Jiménez-Heffernan JA, Pérez-Moat A, GrAntibodies J, López-Alcorocho JM, Carrion V. (2004): Detection of occult Hepatitis C virus infection in patients in whom the etiology of continually Abnormal results of liver-function tests is unknown. J Infect Dis; 189: 7-14.

[4] Comer M, Dal Moline G, D'Amato P, Croce SL, Tribally C, Campbell C. (2006): hepatitis C virus, HBV, and TTV detection by in situ polymerase chain reaction could detect occult infection in hepatocellular carcinoma: comparison with blood markers. J Clan Pathos; 59: 526-529.

[5] Ides, M., All, A., Malik, F. A., Husain, A., Redman, I. U., Akbar, H., Butt, S., Ali, M., Ali, L. \& Malik, F. A. (2010): Occult Hepatitis $\mathrm{C}$ virus infection and linked with predictive factors: The Pakistan experience. Infect Genet Evil, Vol., No., pp. 1567-7257.

[6] Nicot, F., Kumar, N., Mariam, B., Roasting, L., Acquire, C. \& Isopod, J. (2010): No proof of occult Hepatitis C virus (HEPATITIS C VIRUS) infection in serum of HEPATITIS C VIRUS antibody-positive HEPATITIS C VIRUS RNAnegative kidney-transplant patients. Transept Into, Vol. 23, No. 6, pp. (594-601), 0934-0874.

[7] Tsutsumi M, Urashima S, Takada A, and Date T, Tanaka Y. (1994): Detection of antigens related to Hepatitis C virus RNA encoding the NS5 region in the livers of patients with chronic type C Hepatitis. Hematology; 19: 265-72.

[8] Forms X, Bush J. (1999): Hepatitis C virus molecular biology: genotypes and quasispecies. Clan Liver Dis; 3: 693-716. 
[9] Hope RG, MacLauchlan J. (2000): Hepatitis C virus core protein contains unique sequence motifs required for lipid droplet association and protein stability. J Gen Viral; 81: 1913-25.

[10] Mallard P, Kaczynski K, Mickiewicz J, Brunner C, Sidorkiewicz M, Gounod P, et al. (2001): Serum of infected patients with Hepatitis $C$ virus contains No enveloped nucleocapsids. J Viral; 75: 8240-50.

[11] Alzahrani J and Obeid E. (2004): Detection of Hepatitis virus core antigen in blood donors using a new enzyme immunoassay. J Family Community Med; 11 (3): 103-10.

[12] De Marco L, Gillio-Tos A, Piano V, Rondo G, Krogh V, Pallid D, Panic S, Domino R, Vines P, Marlette F, Richard L, Sacerdotal C. (2009): Unexpected finding in a people unselected for hepatic disease. Plops one; 4: e8128.

[13] Welker MW and Seize S. (2009): Occult Hepatitis C: the convincing of current data? J of Hepatic; 49: 665-675.

[14] Castillo I, Bartolommeo J, Quinoa JA, Barrel G, Carrion V. (2010): Detection of occult Hepatitis C without the need for a liver biopsy. J Med Viral; 82: 1554-1559.

[15] Welker MW and Seize S. (2009): Occult Hepatitis C: how convincing are the current data? J of Hepatic; 49: 665-675.

[16] Alzahrani J and Obeid E. (2004): Detection of Hepatitis virus core antigen in blood donors using a new enzyme immunoassay. J Family Community Med; 11 (3): 103-10.

[17] Mustafa A., Koura S. E. and Adel A. (2013): Occult hepatitis $\mathrm{C}$ virus in Egyptian volunteer blood donors, The Egyptian $\mathrm{J}$ of Hospital Medicine, Vol. 50, P103 - 107.

[18] De Marco L, Manzoni P, Treviso M, Gillio-Tos A, Danielle F, Balloon C, et al. (2012): Detection and follow-up of occult hepatitis $\mathrm{C}$ virus infection in an Italian population free of clinically detectable infectious liver disease. Plops One. 7 (8).

[19] Kelvin H., Bokharaei-Salim. 1, Hamidreza. S, Esghaei. M, Nassir. M, Fakhim. S, Sadigh. Z, Moaned. S (2013): Occult Hepatitis C Virus Infection in Candidates for Liver Transplant With Cryptogenic Cirrhosis, Hepatitis Monthly, Vol. 13, No (8): e11290.

[20] Samir S, Nasr A, El Zanily T, Saied R and Matter M (2012): Prevalence of Occult Hepatitis C Virus in Egyptian Patients with Chronic Lymph proliferative Disorders, Hepatitis Research and Treatment, Volume 2012, 6 pages.

[21] Shazly YE, Hamada K, Rafi M, Staff RA, Ali-Eldon ZA, Gad Allah S. (2015): Detection of occult Hepatitis C virus among healthy spouses of patients with hepatitis $\mathrm{C}$ virus infection. $\mathrm{J}$ Med Viral 87: 424-4.

[22] Abdelrahim. S, Khairy. R, abdel-Monem. M, Ragas', AbdelHamid, (2016): Occult Hepatitis C Virus Infection among Egyptian Hemodialysis Patients, J. Med. Viral. DOI 10.1002.

[23] Maria de la Luz Martinez-Rodríguez, Luis A. Uribe-Rogues (2018) Prevalence and risk factors of Occult Hepatitis C infections in blood donors from Mexico City.

[24] Lin H, Chen X, Zhu S, Mao P, Zhu S, Liu Y, et al. (2016) Prevalence of Occult Hepatitis C Virus Infection among Blood Donors in Jiangsu, China. Intervirology 59: 204-210. pmid: 28208127.

[25] Quinoa JA, Avalon A, Bartolommeo J, Andréa M, Flores E,
González MI, et al. (2016) Detection of Hepatitis C virus (HEPATITIS C VIRUS) core-specific antibody suggests occult hepatitis $\mathrm{C}$ virus infection among blood donors. Transfusion 56: 1883-1890. pmid: 27185049.

[26] Daniel H, Vivekananda P, Raghu Raman S, Sridhar and G, Candy GM, Abraham P. (2007): Significance of the Hepatitis $\mathrm{C}$ virus (hepatitis $\mathrm{C}$ virus) core antigen as an alternative plasma marker of active hepatitis $\mathrm{C}$ virus infection. Indian $\mathrm{J}$ Med Microbial; 25: 37-42.

[27] Tanaka E, Hue C, Aoyagi K, Yamaguchi K, Yogi S, Kiyosawa K, Alter HJ. (2000): Evaluation of a new enzyme immunoassay for Hepatitis C virus (hepatitis C virus) core antigen with clinical sensitivity approximating that of genomic amplification of hepatitis C virus RNA. Hematology; 32: 388-393.

[28] Hayashi K, Hastie S, Kusumoto K, Idol A, Ute H, Kenji N, Kothari M, Stover SO., Tsubouchi H. (2005): Usefulness of a new immune-radiometric assay to detect Hepatitis $\mathrm{C}$ core antigen in a community-based population. J Viral Heat; 12: 106-110.

[29] Alzahrani J and Obeid E. (2004): Detection of Hepatitis virus core antigen in blood donors using a new enzyme immunoassay. J Family Community Med; 11 (3): 103-10.

[30] Gaul; dy C, Thevenas. C, Ticket. J, Mariotte. N, Gouda. A, Frederic Dubois (2005): Usefulness of the Hepatitis C Virus Core Antigen Assay for Screening of a Population Undergoing Routine Medical Checkup. J of Clinical Microbiology: Vol. 43, p. 1722-1726.

[31] Lune F, Villon P, Orchard-Hubert I, Loustaud-Ratti V, Sylvain C, et al. (2003): Antiviral effect of ribavirin in early nonresponders to interferon immunotherapy assessed by kinetics of Hepatitis $\mathrm{C}$ virus RNA and Hepatitis $\mathrm{C}$ virus core antigen. $\mathrm{J}$ Hepatic; 39: 826-33.

[32] Juan A. Quinoa, Immaculate Castillo, Margarita Prado, Elena Rodriguez- Indigo, and Vicente Carren o (2006): Combined Hepatitis C Virus (hepatitis C virus) Antigen-Antibody Detection Assay Does Not Improve Diagnosis for Seronegative Individuals with Occult hepatitis $\mathrm{C}$ virus Infection, J of Clinical Microbiology: Vol. 44, No. 12, p. $4559-4560$

[33] Alzahrani J and Obeid E. (2004): Detection of Hepatitis virus core antigen in blood donors using a new enzyme immunoassay. J Family Community Med; 11 (3): 103-10.

[34] Castillo, E Rodrı'guez-Iñigo, J Bartolommeo', S de Lucas, N Ortı'z-Movilla, J MLo'pez-Alcorocho, and M Prado, V Carren o. (2005): Hepatitis C virus replicates in peripheral blood mononuclear cells of patients with occult Hepatitis C virus infection. J Gut; 54: 682-685.

[35] Castillo I, Rodr'iguez-Irnigo E, L'opez-Alcorocho JM, Bartolommeo J, Prado M, Careen V. (2007): Comparative study on the clinical and biological characteristics among patients with single occult Hepatitis B virus (HBV), single occult Hepatitis C virus (hepatitis $C$ virus) and occult HBV and HEPATITIS C VIRUS dual infection, J Med Viral, vol. 79, no. 3, pp. 236-241, 2007.

[36] L'opez-Alcorocho JM, Rodr'1guez-Irnigo E, Castillo I, et al. (2007): The role of genomic and antigenic HEPATITIS C VIRUS -RNA strands as predictive factors of response to paginated interferon plus ribavirin therapy, Alimentary Pharmacology and Therapeutics, vol. 25, no. 10, pp. 11931201, 2007. 
[37] Samir S, Nasr A, El Zanily T, Saied R and Matter M (2012): Prevalence of Occult Hepatitis C Virus in Egyptian Patients with Chronic Lymph proliferative Disorders, Hepatitis Research and Treatment, Volume 2012, 6 pages.

[38] Sad Y, Zachariah S, Ramsey I, El Rainy M, Shaker O, Leaked W, Said M, Nosier M, El-Daly M, Abdel Hamid M, Emit G. (2011): Prevalence of occult Hepatitis C in Egyptian patients with non alcoholic fatty liver disease. Open Journal of Internal Medicine; 1, 33-37.
[39] Kevin H., Bokharaei-Salim. 1, Hamidreza. S, Esghaei. M, Nassir. M, Fakhim. S, Sadigh. Z, Moaned. S (2013): Occult Hepatitis C Virus Infection in Candidates for Liver Transplant With Cryptogenic Cirrhosis, Hepatitis Monthly, Vol. 13, No (8): e11290.

[40] Abdel Rahim, Khairy. R, Abdel-Monem. M, Ragas', AbdelHamid (2016): Occult Hepatitis C Virus Infection among Egyptian Hemodialysis Patients, J. Med. Viral. DOI 10.1002. 